\title{
Dietary live yeast and mannan-oligosaccharide supplementation attenuate intestinal inflammation and barrier dysfunction induced by Escherichia coli in broilers
}

\author{
Weiwei Wang ${ }^{1}$, Zhui $\mathrm{Li}^{1}$, Qiqi Han ${ }^{1}$, Yuming Guo ${ }^{1 *}$, Bo Zhang ${ }^{2}$ and Romain D'inca ${ }^{3}$ \\ ${ }^{1}$ State Key Laboratory of Animal Nutrition, College of Animal Science and Technology, China Agricultural University, \\ Beijing, 100193, People's Republic of China \\ ${ }^{2}$ Phileo Lesaffre Animal Care (China), Beijing, 100027, People's Republic of China \\ ${ }^{3}$ Phileo Lesaffre Animal Care, Lille, 59700, France \\ (Submitted 7 July 2016 - Final revision received 25 October 2016 - Accepted 31 October 2016 - First published online 19 December 2016)
}

\section{Abstract}

The effects of live yeast (LY) and mannan-oligosaccharide (MOS) supplementation on intestinal disruption induced by Escherichia coli in broilers were investigated. The experimental design was a $3 \times 2$ factorial arrangement with three dietary treatments (control, $0 \cdot 5 \mathrm{~g} / \mathrm{kg}$ LY (Saccharomyces cerevisiae, $1.0 \times 10^{10}$ colony-forming units $/ \mathrm{g}$ ), $0.5 \mathrm{~g} / \mathrm{kg}$ MOS) and two immune treatments (with or without $E$. coli challenge from 7 to $11 \mathrm{~d}$ of age). Samples were collected at $14 \mathrm{~d}$ of age. The results showed that $E$. coli challenge impaired $(P<0 \cdot 05)$ growth performance during the grower period $(1-21 \mathrm{~d})$ and the overall period $(1-35 \mathrm{~d})$ of broilers, increased $(P<0 \cdot 05)$ serum endotoxin and diamine oxidase levels coupled with ileal myeloperoxidase and lysozyme activities, whereas reduced $(P<0.05)$ maltase activity, and compromised the morphological structure of the ileum. Besides, it increased $(P<0.05)$ the mRNA expressions of several inflammatory genes and reduced occludin expression in the ileum. Dietary treatment with both LY and MOS reduced $(P<0.05)$ serum diamine oxidase and ileal myeloperoxidase levels, but elevated villus height $(P<0 \cdot 10)$ and the ratio of villus height:crypt depth $(P<0 \cdot 05)$ of the ileum. It also alleviated $(P<0.05) E$. coli-induced increases $(P<0.05)$ in ileal Toll-like receptor $4, N F-\kappa B$ and $I L-1 \beta$ expressions. Moreover, LY supplementation reduced $(P<0.05)$ feed conversion ratio of birds during the grower period and enhanced $(P<0.05)$ the community diversity (Shannon and Simpson indices) of ileal microbiota, whereas MOS addition counteracted $(P<0.05)$ the decreased ileal $I L-10$ and occludin expressions in challenged birds. In conclusion, both LY and MOS supplementation could attenuate $E$. coli-induced intestinal disruption by alleviating intestinal inflammation and barrier dysfunction in broilers. Moreover, LY addition could improve intestinal microbial community structure and feed efficiency of broilers.

Key words: Live yeast: Mannan-oligosaccharide: Broilers: Intestinal inflammation: Intestinal barrier dysfunction

Challenge by pathogenic Escherichia coli is responsible for a large variety of disorders in production, resulting in intestinal disruption and subsequent compromise in growth performance of chickens ${ }^{(1-3)}$. In the past few decades, antibiotics were widely used to prevent or control E. coli infection in animals. However, antibiotic treatment led to increasing drug residues and drug-resistant bacteria and affected the health of animals. As a consequence, alternatives to antibiotics that could be applied to control or attenuate colibacillosis are necessary to protect the health status and growth performance of chickens. Recent studies have focused on the importance of probiotics and prebiotics as potential substitutes for antibiotics to alleviate bacteria-related immune dysfunction and intestinal damage, as well as impaired performance in chickens ${ }^{(2,4-7)}$.
Mannan-oligosaccharide (MOS) holds an important position among multifarious prebiotics, which has been indicated to suppress the adhesion of some bacteria to the gut ${ }^{(8)}$ and exert beneficial effects on growth performance, intestinal immunity and structure as well as gut microflora in broilers ${ }^{(5,9,10)}$. However, a few studies have been carried out on whether MOS addition could alleviate intestinal inflammation and protect the intestinal barrier against bacteria in broilers.

An important constituent of probiotics is live yeast (LY, Saccharomyces cerevisiae) that has been reported to modulate intestinal microbial balance ${ }^{(11,12)}$, improve humoral immune responses and intestinal structure and function of animals ${ }^{(12-14)}$. Furthermore, LY addition was indicated to mitigate bacteriaassociated immunological derangement and intestinal disorders

Abbreviations: ABW, average body weight; ADFI, average daily feed intake; ADG, average daily gain; DAO, diamine oxidase; FCR, feed conversion ratio; LY, live yeast; MOS, mannan-oligosaccharide; MPO, myeloperoxidase; TJ, tight junctions; TLR, Toll-like receptor; VCR, villus height:crypt depth ratio.

* Corresponding author: Y. Guo, fax +860106273 2712, email guoyum@cau.edu.cn 
in pigs ${ }^{(15-17)}$ and to attenuate pathogen-induced intestinal inflammation in mice ${ }^{(18)}$. Similar results were also found in in vitro studies, where LY treatment reduced the expressions of pro-inflammatory cytokines and increased the expressions of anti-inflammatory cytokines of porcine intestinal epithelial cells following bacterial invasion ${ }^{(19,20)}$. Nevertheless, an understanding of the effects of LY addition on intestinal inflammation and barrier function in infected chickens is lacking. Therefore, the present study was conducted to determine the effects of supplemental LY and MOS on intestinal inflammatory responses and barrier function in broilers challenged with $E$. coli.

\section{Methods}

\section{Birds and experimental design}

The experimental animal protocol for this study was approved by the Animal Care and Use Committee of China Agricultural University. The experimental design was a $3 \times 2$ factorial arrangement. A total of 540 1-d-old male Arbor Acre broilers were randomly divided into three treatment groups with two subgroups each (nine replicates). Initial body weights were similar across all the groups. Birds received mashed basal diets with or without $0.5 \mathrm{~g} / \mathrm{kg}$ MOS (SAF-mannan; Phileo Lesaffre Animal Care) or $0.5 \mathrm{~g} / \mathrm{kg}$ LY (S. cerevisiae Actisaf Sc 47 , $1 \cdot 0 \times 10^{10}$ colony-forming units (CFU)/g; Phileo Lesaffre Animal Care) throughout the trial period. The composition of the basal diets is shown in Table 1 . All birds were maintained in wirefloored cages in a three-level battery on their respective diets, and were vaccinated using combined Newcastle disease virus

Table 1. Composition of the experimental diets $(\mathrm{g} / \mathrm{kg})$

\begin{tabular}{|c|c|c|}
\hline \multirow[b]{2}{*}{ Ingredients } & \multicolumn{2}{|c|}{ Stage } \\
\hline & $1-21 d$ & $22-35 d$ \\
\hline Maize & $559 \cdot 7$ & 613.7 \\
\hline Soyabean meal & $376 \cdot 3$ & 318.8 \\
\hline Soyabean oil & 23.7 & $31 \cdot 3$ \\
\hline Limestone & $12 \cdot 7$ & $12 \cdot 1$ \\
\hline Sodium chloride & 3.5 & 3.5 \\
\hline Dicalcium phosphate & $17 \cdot 5$ & 14.9 \\
\hline Choline chloride (50\%) & $2 \cdot 0$ & $2 \cdot 0$ \\
\hline DL-Met (98\%) & $2 \cdot 0$ & 1.2 \\
\hline L-Lys $\mathrm{HCl}(99 \%)$ & 0.2 & 0.1 \\
\hline Antioxidant & 0.2 & 0.2 \\
\hline Multimineral $^{*}$ & 0.2 & 0.2 \\
\hline Multivitamin $\dagger$ & $2 \cdot 0$ & $2 \cdot 0$ \\
\hline MOS/yeastł & \pm & \pm \\
\hline \multicolumn{3}{|l|}{ Nutrient levels } \\
\hline Metabolisable energy (MJ/kg) & $12 \cdot 14$ & 12.56 \\
\hline Crude protein & 210.0 & 190.0 \\
\hline Available P & 4.5 & 4.0 \\
\hline $\mathrm{Ca}$ & $10 \cdot 0$ & 9.0 \\
\hline Lys & 11.5 & $10 \cdot 0$ \\
\hline Met & $5 \cdot 0$ & 4.0 \\
\hline
\end{tabular}

MOS, mannan-oligosaccharide.

* Supplied per kg of diet: Cu, $8 \mathrm{mg} ; \mathrm{Zn}, 75 \mathrm{mg} ; \mathrm{Fe}, 80 \mathrm{mg}$; Mn, $100 \mathrm{mg}$; Se, 0.15 mg; I, $0.35 \mathrm{mg}$.

† Supplied per $\mathrm{kg}$ of diet: retinyl acetate, $24 \mathrm{mg}$; cholecalciferol, $6 \mathrm{mg}$; menadione $2.65 \mathrm{mg}$; thiamin, $2 \mathrm{mg}$; riboflavin, $6 \mathrm{mg}$; cyanocobalamin, $0.025 \mathrm{mg}$; $a$-tocopherol acetate, $20 \mathrm{mg}$; biotin, $0.0325 \mathrm{mg}$; folic acid, $1.25 \mathrm{mg}$; pantothenic acid, $12 \mathrm{mg}$; niacin, $50 \mathrm{mg}$.

$\ddagger$ MOS or yeast was substituted for the same amount of maize. and infectious bronchitis virus at $9 \mathrm{~d}$ of age and infectious bursal disease virus at $21 \mathrm{~d}$ of age via intranasal and intraocular administration. Feed and fresh water were available ad libitum. Birds were maintained at a $20 \mathrm{~h}$ light $-4 \mathrm{~h}$ dark cycle throughout the trial period. Temperature was controlled with heaters and gradually reduced from $35^{\circ} \mathrm{C}$ on $\mathrm{d} 1$ to $24^{\circ} \mathrm{C}$ at $21 \mathrm{~d}$ of age and then kept roughly constant.

\section{Oral challenge and sampling}

The E. coli O78 strain (CVCC1490; China Veterinary Culture Collection Center) was cultured in lactose broth at $37^{\circ} \mathrm{C}$ for $16 \mathrm{~h}$. To enumerate bacteria, inoculum was diluted and plated on MacConkey agar at $37^{\circ} \mathrm{C}$ for $24 \mathrm{~h}$. From 7 to $11 \mathrm{~d}$ of age, half of the birds from each treatment group were orally gavaged with $1 \mathrm{ml}$ of $E$. coli $\mathrm{O} 78$ culture $\left(1.0 \times 10^{9} \mathrm{CFU} / \mathrm{ml}\right)$ or the same amount of lactose broth. One bird per replicate was randomly selected for sample collection at $14 \mathrm{~d}$ of age. Individual blood samples were collected aseptically from the wing vein; serum samples were separated by centrifugation of blood at $3000 \mathrm{rpm}$ for $10 \mathrm{~min}$ at $4^{\circ} \mathrm{C}$ and stored at $-30^{\circ} \mathrm{C}$ until analysed. After blood collection, these birds were slaughtered rapidly, and the midpoints of the jejunum and ileum of each bird were harvested and cut into two segments. One sample was fixed in $4 \%$ paraformaldehyde solution, and the other was frozen in liquid $\mathrm{N}_{2}$ and kept at $-80^{\circ} \mathrm{C}$ for quantification of gene expression. Besides, chyme and mucosa samples were collected from jejunal and ileal segments and quick-freezed using liquid $\mathrm{N}_{2}$, followed by the preservation at $-80^{\circ} \mathrm{C}$ until further analysis.

\section{Performance determination}

Body weight and feed intake of broilers were recorded for each replicate at 21 and $35 \mathrm{~d}$ of age. Average body weight (ABW), average daily gain (ADG), average daily feed intake (ADFI), feed conversion ratio (FCR), mortality during the grower period (1-21d) and the overall period (1-35d) were calculated.

\section{Biochemical assay of serum and intestinal mucosa}

Serum endotoxin was quantified using a quantitative chromogenic substrate assay kit (Xiamen TAL Experimental Plant Co., Ltd). Serum diamine oxidase (DAO) activity was determined colorimetrically using a commercial kit according to the manufacturer's protocols (Huaying Biotechnology Research Institute). Intestinal lysozyme and myeloperoxidase (MPO) activities were also measured using colorimetric kits according to the manufacturer's protocols (Jiancheng Bioengineering Institute). Disaccharidase activity was determined as described previously $^{(21)}$. The results of the above-mentioned intestinal parameters were normalised by total protein content, which was measured using BCA protein quantitation kits (Jiancheng Bioengineering Institute).

\section{Intestinal morphological analyses}

We obtained $4-\mu \mathrm{m}$ cross-sections of jejunal and ileal tissues after staining with haematoxylin-eosin using standard 
paraffin-embedding procedures. From each section, ten longest and intact villi were selected for morphology measurement using Leica DMI6000B light microscope equipped with an image-processing software (Leica application suite V4.2). Villus height $(\mathrm{VH})$ was measured from the tip of villus to the junction of villus and crypt. Crypt depth was defined as the depth of emboli between adjacent villi. Villus width (VW) was defined as the width of the widest point of it. Villus height:crypt depth ratio (VCR) and villus surface area $(\pi \times \mathrm{VH} \times \mathrm{VW})$ were calculated. The mean value of these ten values represents the final value of each sample.

\section{RNA extraction and real-time quantitative $P C R$}

Total RNA was extracted from ileal samples using Trizol reagent (Invitrogen Biotechnology Inc.) and dissolved in RNase-free water. The concentration of extracted RNA was determined using NanoDrop spectrophotometer (ND-2000 UV-Vis; Thermo Scientific Inc.). RNA purity was verified by measuring the absorbance ratio at 260:280 $\mathrm{nm}$. RNA integrity was evaluated on the basis of the spectral curve ${ }^{(22)}$. Total RNA was then reverse transcribed using PrimeScript ${ }^{\mathrm{TM}}$ RT reagent kit with gDNA Eraser (Takara Biotechnology Inc.), and complementary DNA (cDNA) was stored at $-20^{\circ} \mathrm{C}$ until analysed. Real-time PCR for measuring intestinal gene expression was carried out using SYBR $^{\circledR}$ Premix Ex Taq $^{\text {TM }}$ (Tli RNaseH Plus) (Takara Biotechnology Inc.) in ABI 7500 Real Time PCR Systems (Applied Biosystems). The expression of $\beta$-actin was used as an internal control to normalise the amount of initial RNA for each sample. The reaction volume of $20 \mu \mathrm{l}$ mixture contained $10 \mu \mathrm{LSYBR}{ }^{\circledR}$ Premix Ex Taq (Tli RNaseH Plus), 0·4- $\mu$ l ROX reference dye, $0 \cdot 4 \mu \mathrm{l}$ of each forward and reverse primer, $6 \cdot 8-\mu \mathrm{l}$ easy dilution and $2-\mu \mathrm{l}$ cDNA template. The primer sequences for the target and reference genes are shown in Table 2. The optimised protocol for all the genes was $95^{\circ} \mathrm{C}$ for $30 \mathrm{~s}$ followed by forty cycles of $95^{\circ} \mathrm{C}$ for $5 \mathrm{~s}$ and $60^{\circ} \mathrm{C}$ for $34 \mathrm{~s}$. All measurements were

Table 2. Sequences for real-time PCR primers

\begin{tabular}{|c|c|c|}
\hline Genes & Primer sequence $\left(5^{\prime}-3^{\prime}\right)$ & Accession no. \\
\hline \multirow[t]{2}{*}{$\beta$-Actin } & F: GAGAAATTGTGCGTGACATCA & \multirow[t]{2}{*}{ L08165 } \\
\hline & R: CCTGAACCTCTCATTGCCA & \\
\hline \multirow[t]{2}{*}{ TLR4 } & F: GTTCCTGCTGAAATCCCAAA & \multirow[t]{2}{*}{ NM_001030693 } \\
\hline & R: TATGGATGTGGCACCTTGAA & \\
\hline \multirow[t]{2}{*}{$N F-\kappa B p 65$} & F: GTGTGAAGAAACGGGAACTG & \multirow[t]{2}{*}{ NM_205129 } \\
\hline & R: GGCACGGTTGTCATAGATGG & \\
\hline \multirow[t]{2}{*}{$I L-1 \beta$} & F: ACTGGGCATCAAGGGCTA & \multirow[t]{2}{*}{ NM_204524 } \\
\hline & R: GGTAGAAGATGAAGCGGGTC & \\
\hline$T N F-a$ & $\begin{array}{l}\text { F: GAGCGTTGACTTGGCTGTC } \\
\text { R: AAGCAACAACCAGCTATGCAC }\end{array}$ & NM_204267 \\
\hline \multirow[t]{2}{*}{$I L-10$} & F: CGGGAGCTGAGGGTGAA & \multirow[t]{2}{*}{ AJ621614 } \\
\hline & R: GTGAAGAAGCGGTGACAGC & \\
\hline \multirow[t]{2}{*}{ IL-8 } & F: ATGAACGGCAAGCTTGGAGCTG & \multirow[t]{2}{*}{ AJ009800 } \\
\hline & R: TCCAAGCACACCTCTCTTCCATCC & \\
\hline \multirow[t]{2}{*}{ Claudin-1 } & F: CATACTCCTGGGTCTGGTTGGT & \multirow[t]{2}{*}{ AY750897.1 } \\
\hline & R: GACAGCCATCCGCATCTTCT & \\
\hline \multirow[t]{2}{*}{ Occludin } & F: ACGGCAGCACCTACCTCAA & \multirow[t]{2}{*}{ D21837.1 } \\
\hline & R: GGGCGAAGAAGCAGATGAG & \\
\hline$Z O-1$ & $\begin{array}{l}\text { F: CTTCAGGTGTTTCTCTTCCTCCTC } \\
\text { R: CTGTGGTTTCATGGCTGGATC }\end{array}$ & XM_413773 \\
\hline
\end{tabular}

F, forward; $\mathrm{R}$, reverse; $T L R 4$, Toll-like receptor 4 ; $Z O$, zonula occludens. carried out in triplicate, and the average values were obtained. Real-time PCR efficiency for each gene was calculated on the basis of the slope of cDNA relative standard curve that was generated using pooled samples. The efficiency values between the reference gene and target genes were consistent. The abundance of $\beta$-actin mRNA was not affected by dietary treatment or $E$. coli challenge. Specificity of PCR products was evaluated by the analysis of melting curve. The results of relative mRNA expression of intestinal genes were calculated using the $2^{-\Delta \Delta C_{t}} \operatorname{method}^{(23)}$

\section{Pyrosequencing of ileal microbiota}

DNA samples were extracted from ileal digesta using QIAamp DNA Stool Mini Kits (Qiagen Inc.) according to the manufacturer's protocol. The concentration and quality of extracted DNA were checked with gel electrophoresis and NanoDrop 2000 spectrophotometer. Bacterial 16S rRNA sequences spanning the variable regions $\mathrm{V} 3-\mathrm{V} 4$ were amplified using primer 515F (5'-GTG CCA GCM GCC GCG GTA A-3') and 806R (5'-GGA CTA CHV GGG TWT CTA AT-3'). A 10-ng aliquot of each sample DNA was used for PCR reaction using TransStart FastPfu DNA Polymerase in a $20-\mu$ l reaction volume. Amplification by PCR consisted of the following steps: denaturation at $95^{\circ} \mathrm{C}$ for $3 \mathrm{~min}$, twenty-eight cycles of $30 \mathrm{~s}$ at $95^{\circ} \mathrm{C}, 55^{\circ} \mathrm{C}$ for $30 \mathrm{~s}$, and $72^{\circ} \mathrm{C}$ for $45 \mathrm{~s}$, and extension at $72^{\circ} \mathrm{C}$ for $10 \mathrm{~min}$. The PCR products were detected by $2 \%$ agarose gel electrophoresis and purified with QIAquick Gel Extraction Kit (Qiagen Inc.). A DNA Library was constructed using TruSeq ${ }^{\circledR}$ DNA PCR-Free Sample Preparation Kit (Illumina) and detected by Qubit and q-PCR quantification. Pyrosequencing was carried out on the Illumina HiSeq2500 PE250 platform (Illumina). All the procedures were conducted by Novogene Bioinformatics Technology Co., Ltd. Sample reads were assembled using mothur software. Clustering of filtered sequences into operational taxonomic units (OTU) was achieved using Uparse at 97\% sequence identity. Taxonomic classification at different taxonomic levels of these OTU sequences was performed by comparing sequences with the GreenGene database. Qiime software and Python scripts were used for the analysis of microbial diversity. $\alpha$-Diversity metrics including Shannon, Simpson, Chao1 and abundance-based coverage estimator (ACE) indices were calculated. $\beta$-Diversity (UniFrac distances) was visualised by principal component analysis (PCA) and principal coordinates analysis (PCOA).

\section{Statistical analysis}

Data are presented as mean values with their standard errors and analysed by two-way ANOVA to measure the main effects of dietary treatment and E. coli challenge using the general linear model procedure of SPSS 18.0 software. Differences between different groups were analysed by Duncan's multiple comparisons. Significance was set at $P<0.05$, and $0.05<P<0.10$ was viewed as a trend towards significance. One-way ANOVA was used to analyse the results if interaction was significant. 


\section{Results}

\section{Growth performance}

E. coli challenge reduced $(P<0.05) \mathrm{ABW}$ of birds on d 21 and 35 , as well as ADG and ADFI during the grower period coupled with ADG during the overall period (Table 3). Besides, there was an increase in $(P<0.05)$ FCR during the grower period, along with a decreasing trend for ADFI $(P<0 \cdot 10)$ during the overall period in response to the challenge. Dietary treatment with LY or MOS did not modify $(P>0.05)$ ABW, ADG and ADFI of broilers, but the addition of LY reduced $(P<0.05)$ FCR of birds during the grower period. The increased mortality of birds due to $E$. coli challenge was not influenced $(P>0.05)$ by dietary treatment (data not shown).

\section{Serum and intestinal biochemical parameters}

Challenged groups had higher $(P<0.05)$ endotoxin and DAO levels in serum as well as MPO and lysozyme activities in the ileum compared with unchallenged groups (Table 4). A decreasing trend $(P<0 \cdot 10)$ of maltase activity in the jejunum and a reduction $(P<0.05)$ of it in the ileum were recorded after E. coli challenge. Dietary treatment with both LY and MOS reduced $(P<0.05)$ serum DAO activity and ileal MPO activity, and tended to alleviate $(P<0 \cdot 10) E$. coli-induced increase in serum endotoxin content.

\section{Intestinal morphology structure}

As shown in Table 5, E. coli challenge resulted in a reduction $(P<0.05)$ in jejunal VCR and a decreasing trend $(P<0.10)$ in ileal VCR. There was an increase in $(P<0.05)$ ileal VCR and a tendency towards an increased $(P<0 \cdot 10) \mathrm{VH}$ in the ileum after dietary treatment with both LY and MOS.

\section{Relative mRNA expression of ileal genes}

E. coli challenge increased $(P<0.05)$ the mRNA expressions of ileal Toll-like receptor 4 (TLR4),NF- $\kappa B, I L-1 \beta$ and $I L-8$, but tended to down-regulate $(P<0 \cdot 10)$ ileal $I L-10$ expression (Fig. 1). There were interactions $(P<0.05)$ between dietary treatment and $E$. coli challenge on ileal TLR4, NF- $\kappa B$ and $I L-1 \beta$ expressions, as exhibited by the mitigatory effects $(P<0.05)$ of dietary treatment with both LY and MOS on the elevated $(P<0.05)$ expressions of ileal TLR4, NF- $\kappa B$ and $I L-1 \beta$ in challenged birds. In addition, LY-treated birds showed higher $(P<0.05)$ ileal $T N F-\alpha$ expression compared with unchallenged birds. Administration of MOS into challenged birds prevented $(P<0.05)$ the reduction in $I L-10$ expression. A reduced $(P<0.05)$ expression of ileal occludin and a decreasing trend $(P<0 \cdot 10)$ of ileal zonula occludens $(Z O)-1$ expression were observed because of $E$. coli challenge (Fig. 2). The effect of dietary treatment $(P>0.05)$ with MOS or LY was not noted for ileal claudin-1 and ZO-1 expressions. However, there was an interaction $(P<0.05)$ between $E$. coli challenge and dietary treatment on ileal occludin expression, as evidenced by the counteraction $(P<0.05)$ of the reduced occludin expression in challenged birds due to MOS addition.

\section{Composition and community diversity of ileal microbiota}

E. coli challenge decreased $(P<0.05)$ the relative abundance of ileal Enterococcus, and showed a trend towards an increase $(P<0.10)$ in the relative abundance of Ruminococcus in the ileum of broilers (Table 6 ). LY addition showed a trend towards an increase $(P<0 \cdot 10)$ in the relative abundance of ileal Enterococcus and Brevibacillus of broilers. As shown in Table 7 , LY addition increased $(P<0.05)$ Shannon and Simpson indices of ileal microbiota and tended to elevate $(P<0 \cdot 10)$ Chao1 and ACE indices of ileal microbiota in challenged birds.

Table 3. Effects of dietary treatment on growth performance of broilers challenged with Escherichia coli

(Mean values with their standard errors; $n$ 9)

\begin{tabular}{|c|c|c|c|c|c|c|c|c|c|}
\hline & \multirow[b]{2}{*}{ E. coli } & \multirow{2}{*}{$\frac{21 \mathrm{~d}}{\mathrm{ABW}}$} & \multicolumn{3}{|c|}{$1-21 d$} & \multirow{2}{*}{$\frac{35 d}{A B W}$} & \multicolumn{3}{|c|}{$1-35 d$} \\
\hline & & & ADG & ADFI & FCR & & $A D G$ & ADFI & FCR \\
\hline \multicolumn{10}{|l|}{ Diet } \\
\hline \multirow[t]{2}{*}{ Cont } & - & 734 & $32 \cdot 8$ & $46 \cdot 1$ & 1.41 & 1937 & $54 \cdot 1$ & 92.6 & 1.72 \\
\hline & + & 691 & $30 \cdot 8$ & $45 \cdot 1$ & 1.47 & 1873 & $52 \cdot 2$ & 90.5 & 1.73 \\
\hline \multirow[t]{2}{*}{ MOS } & - & 763 & 34.2 & 48.0 & 1.40 & 1998 & 55.8 & 94.1 & 1.69 \\
\hline & + & 700 & 31.2 & $44 \cdot 3$ & 1.42 & 1894 & $52 \cdot 8$ & 91.0 & 1.73 \\
\hline \multirow[t]{2}{*}{ LY } & - & 759 & $34 \cdot 0$ & $46 \cdot 3$ & 1.36 & 1991 & $55 \cdot 6$ & 91.6 & 1.65 \\
\hline & + & 696 & 31.0 & 43.8 & 1.42 & 1903 & $53 \cdot 1$ & $90 \cdot 1$ & 1.70 \\
\hline SEM & & $5 \cdot 0$ & 0.24 & 0.40 & 0.007 & 11.4 & 0.33 & 0.64 & 0.011 \\
\hline \multicolumn{10}{|l|}{ Main effects } \\
\hline Cont & & 712 & $31 \cdot 8$ & $45 \cdot 6$ & $1.44^{\mathrm{a}}$ & 1905 & $53 \cdot 1$ & 91.6 & 1.73 \\
\hline MOS & & 732 & 32.7 & $46 \cdot 1$ & $1.41^{\mathrm{a}, \mathrm{b}}$ & 1946 & 54.3 & 92.6 & 1.71 \\
\hline \multirow[t]{3}{*}{ LY } & & 728 & 32.5 & $45 \cdot 1$ & $1.39^{b}$ & 1947 & 54.3 & 90.8 & 1.67 \\
\hline & - & $752^{\mathrm{a}}$ & $33 \cdot 7^{\mathrm{a}}$ & $46 \cdot 8^{a}$ & $1.39^{b}$ & $1976^{\mathrm{a}}$ & $55 \cdot 1^{a}$ & $92 \cdot 8$ & 1.68 \\
\hline & + & $696^{\mathrm{b}}$ & $31 \cdot 0^{\mathrm{b}}$ & $44 \cdot 4^{b}$ & $1.44^{\mathrm{a}}$ & $1890^{b}$ & $52 \cdot 7^{\mathrm{b}}$ & 90.5 & 1.72 \\
\hline \multicolumn{10}{|l|}{$P$} \\
\hline Diet & & 0.260 & 0.261 & 0.581 & 0.030 & 0.237 & 0.237 & 0.537 & 0.158 \\
\hline E. coli & & $<0.001$ & $<0.001$ & 0.004 & 0.004 & $<0.001$ & $<0.001$ & 0.087 & 0.131 \\
\hline Interaction & & 0.614 & 0.614 & 0.373 & 0.430 & 0.780 & 0.781 & 0.882 & 0.832 \\
\hline
\end{tabular}

ABW, average body weight (g); ADG, average daily gain (g); ADFI, average daily feed intake (g); FCR, feed conversion ratio; Cont, control; MOS, mannan-oligosaccharide; LY, live yeast.

${ }_{\mathrm{a}, \mathrm{b}}$ Mean values within a column with unlike superscript letters are significantly different $(P<0.05)$. 
Table 4. Effects of dietary treatment on serum and intestinal biochemical parameters of broilers challenged with Escherichia coli (Mean values with their standard errors; $n$ 9)

\begin{tabular}{|c|c|c|c|c|c|c|c|c|c|c|c|}
\hline & \multirow[b]{2}{*}{ E. coli } & \multicolumn{2}{|c|}{ Serum } & \multicolumn{4}{|c|}{ Jejunum } & \multicolumn{4}{|c|}{ Ileum } \\
\hline & & Edtx & DAO & Mal & Suc & MPO & Lys & Mal & Suc & MPO & Lys \\
\hline \multicolumn{12}{|l|}{ Diet } \\
\hline \multirow[t]{2}{*}{ Cont } & - & 0.32 & $1.30^{\mathrm{b}}$ & 233.1 & $132 \cdot 1$ & 0.090 & 3.89 & 228.1 & 81.5 & 0.184 & 7.83 \\
\hline & + & 0.46 & $2 \cdot 18^{\mathrm{a}}$ & 193.5 & 119.1 & 0.114 & 4.85 & 194.7 & $77 \cdot 2$ & 0.302 & 9.92 \\
\hline \multirow{2}{*}{ MOS } & - & 0.35 & $1.32^{\mathrm{b}}$ & 233.9 & 125.5 & 0.084 & 3.73 & 208.0 & 83.8 & 0.160 & 7.56 \\
\hline & + & 0.40 & $1.24^{b}$ & 231.3 & 123.2 & 0.092 & 4.45 & 189.0 & 83.4 & 0.253 & 9.49 \\
\hline \multirow[t]{2}{*}{ LY } & - & 0.33 & $1.33^{\mathrm{b}}$ & 211.9 & $142 \cdot 1$ & 0.094 & $4 \cdot 18$ & 241.0 & 83.9 & 0.135 & 8.09 \\
\hline & + & 0.44 & $1.35^{\mathrm{b}}$ & $191 \cdot 2$ & $105 \cdot 8$ & 0.102 & $4 \cdot 38$ & 222.5 & $72 \cdot 1$ & 0.241 & 9.59 \\
\hline SEM & & 0.007 & 0.040 & $5 \cdot 87$ & $6 \cdot 29$ & 0.004 & 0.177 & 4.19 & 1.74 & 0.005 & 0.341 \\
\hline \multicolumn{12}{|l|}{ Main effects } \\
\hline Cont & & 0.39 & $1.74^{\mathrm{a}}$ & $213 \cdot 3$ & $125 \cdot 6$ & 0.102 & $4 \cdot 37$ & $211 \cdot 4^{\mathrm{a}, \mathrm{b}}$ & $79 \cdot 4$ & $0.243^{a}$ & 8.88 \\
\hline MOS & & 0.38 & $1.28^{\mathrm{b}}$ & $232 \cdot 6$ & 124.4 & 0.088 & 4.09 & $198 \cdot 5^{\mathrm{b}}$ & 83.6 & $0.206^{b}$ & 8.52 \\
\hline \multirow[t]{3}{*}{ LY } & & 0.39 & $1.34^{\mathrm{b}}$ & 201.6 & 123.9 & 0.098 & $4 \cdot 28$ & $231.7^{\mathrm{a}}$ & 78.0 & $0 \cdot 188^{b}$ & 8.84 \\
\hline & - & $0.33^{b}$ & $1.32^{b}$ & $226 \cdot 3$ & $133 \cdot 3$ & 0.089 & 3.93 & $225 \cdot 7^{a}$ & $83 \cdot 1$ & $0 \cdot 160^{\mathrm{b}}$ & $7 \cdot 83^{b}$ \\
\hline & + & $0.44^{\mathrm{a}}$ & $1.59^{a}$ & $205 \cdot 4$ & $116 \cdot 0$ & 0.103 & 4.56 & $202 \cdot 1^{\mathrm{b}}$ & 77.6 & $0.265^{a}$ & $9.67^{a}$ \\
\hline \multicolumn{12}{|l|}{$P$} \\
\hline Diet & & 0.734 & $<0.001$ & 0.103 & 0.994 & 0.324 & 0.803 & 0.008 & 0.398 & $<0.001$ & 0.899 \\
\hline E. coli & & $<0.001$ & 0.001 & 0.080 & 0.178 & 0.085 & 0.082 & 0.007 & 0.119 & $<0.001$ & 0.010 \\
\hline Interaction & & 0.052 & $<0.001$ & 0.442 & 0.533 & 0.634 & 0.671 & 0.711 & 0.414 & 0.646 & 0.933 \\
\hline
\end{tabular}

Edtx, endotoxin (EU/ml); DAO, diamine oxidase (U/ml); Mal, maltase (U/g protein); Suc, sucrase (U/g protein); MPO, myeloperoxidase (U/g tissue); Lys, lysozyme (U/mg protein); Cont, control; MOS, mannan-oligosaccharide; LY, live yeast.

a,b Mean values within a column with unlike superscript letters are significantly different $(P<0.05)$.

Table 5. Effects of dietary treatment on the intestinal morphology structure of broilers challenged with Escherichia coli (Mean values with their standard errors; $n$ 9)

\begin{tabular}{|c|c|c|c|c|c|c|c|c|c|c|c|}
\hline & \multirow[b]{2}{*}{ E. coli } & \multicolumn{5}{|c|}{ Jejunum } & \multicolumn{5}{|c|}{ Ileum } \\
\hline & & VH & $C D$ & VW & VCR & VSA & VH & $C D$ & VW & VCR & VSA \\
\hline \multicolumn{12}{|l|}{ Diet } \\
\hline \multirow[t]{2}{*}{ Cont } & - & 1024 & 179 & 230 & $5 \cdot 76$ & 0.74 & 576 & 154 & 198 & 3.84 & 0.36 \\
\hline & + & 899 & 202 & 215 & 4.44 & 0.62 & 461 & 145 & 205 & 3.23 & 0.30 \\
\hline \multirow[t]{2}{*}{ MOS } & - & 1028 & 175 & 261 & 5.99 & 0.85 & 666 & 148 & 213 & 4.72 & 0.45 \\
\hline & + & 982 & 183 & 235 & 5.51 & 0.72 & 534 & 130 & 199 & $4 \cdot 17$ & 0.33 \\
\hline \multirow[t]{2}{*}{ LY } & - & 1068 & 172 & 243 & 6.44 & 0.81 & 629 & 148 & 196 & 4.33 & 0.40 \\
\hline & + & 984 & 177 & 290 & 5.59 & 0.89 & 578 & 144 & 215 & 4.02 & 0.39 \\
\hline SEM & & 31.4 & 6.2 & 7.6 & 0.193 & 0.033 & $15 \cdot 4$ & 4.3 & 6.7 & 0.136 & 0.019 \\
\hline \multicolumn{12}{|l|}{ Main effects } \\
\hline Cont & & 961 & 191 & 222 & $5 \cdot 10$ & 0.68 & 519 & 149 & 201 & $3.53^{b}$ & 0.33 \\
\hline MOS & & 1005 & 179 & 248 & 5.75 & 0.78 & 600 & 139 & 206 & $4.44^{\mathrm{a}}$ & 0.39 \\
\hline \multirow{3}{*}{$\mathrm{LY}$} & & 1026 & 175 & 266 & 6.01 & 0.85 & 604 & 146 & 205 & $4 \cdot 17^{\mathrm{a}}$ & 0.39 \\
\hline & - & 1040 & 176 & 245 & $6.06^{\mathrm{a}}$ & 0.80 & $624^{\mathrm{a}}$ & 150 & 202 & 4.29 & 0.40 \\
\hline & + & 955 & 187 & 246 & $5 \cdot 18^{\mathrm{b}}$ & 0.74 & $524^{\mathrm{b}}$ & 140 & 206 & 3.81 & 0.34 \\
\hline \multicolumn{12}{|l|}{$P$} \\
\hline \multicolumn{2}{|l|}{ Diet } & 0.695 & 0.557 & 0.078 & 0.155 & 0.110 & 0.052 & 0.620 & 0.951 & 0.031 & 0.305 \\
\hline \multicolumn{2}{|l|}{ E. coli } & 0.186 & 0.342 & 0.905 & 0.029 & 0.401 & 0.003 & 0.265 & 0.778 & 0.084 & 0.121 \\
\hline \multicolumn{2}{|l|}{ Interaction } & 0.878 & 0.814 & 0.124 & 0.678 & 0.350 & 0.527 & 0.807 & 0.599 & 0.889 & 0.496 \\
\hline
\end{tabular}

VH, villus height $(\mu \mathrm{m})$; CD, crypt depth $(\mu \mathrm{m})$; VW, villus width $(\mu \mathrm{m})$; VCR, the ratio of VH:CD; VSA, villus surface area (mm²); Cont, control; MOS, mannan-oligosaccharide; LY, live yeast.

a,b Mean values within a column with unlike superscript letters are significantly different $(P<0.05)$.

PCA and PCOA indicated that there was no obvious difference in $\beta$ diversity of ileal microbiota between each group (Fig. 3).

\section{Discussion}

The suppressed growth performance of animals bred in an unclean environment could be a result of intestinal dysfunction induced by bacterial challenge ${ }^{(1-3)}$. In this study, we confirmed the negative effects of $E$. coli challenge on growth performance of broilers, exhibited as reduced ABW, ADG and ADFI accompanied by an increased FCR. Improved growth performance of chickens had been reported following the administration of $\mathrm{MOS}^{(10)}$; however, the different findings are described elsewhere ${ }^{(24)}$. On the other hand, the effects of LY addition on growth performance of animals were also variable ${ }^{(12,25)}$. In this study, dietary treatment with MOS or LY did not affect ABW, ADG and ADFI of broilers independent of the immunological status. However, broilers fed LY had a reduced FCR during the grower period compared with control birds. It could be deduced that application of LY at an early stage appears to 
(A)

$P($ diet $)=0 \cdot 168$

$P$ (challenge $)=0.043$

$P($ interaction $)=0.019$

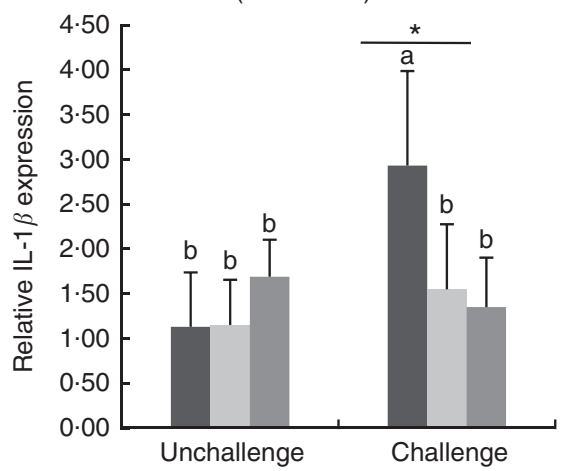

(C)

$P($ diet $)=0.170$

$P$ (challenge $)=0.076$

$P($ interaction $)=0.046$

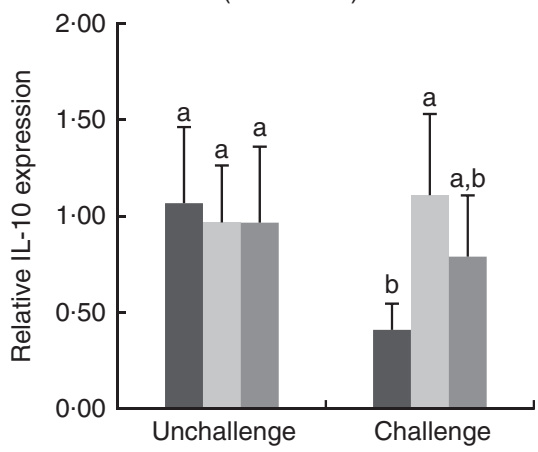

(E)

$P($ diet $)=0.451$

$P$ (challenge $)=0.005$

$P($ interaction $)=0.010$

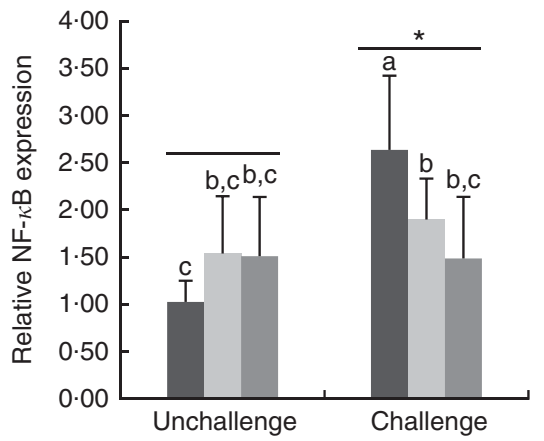

(B)

$P($ diet $)=0.018$

$P$ (challenge $)=0.192$

$P($ interaction $)=0.515$

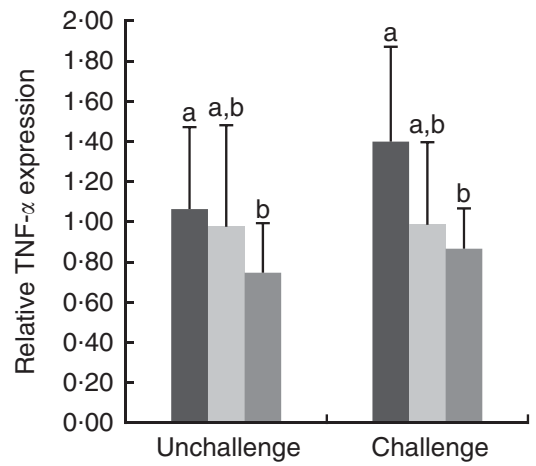

(D)

$P$ (diet) $=0.425$

$P($ challenge $)=0.018$

$P($ interaction $)=0.703$

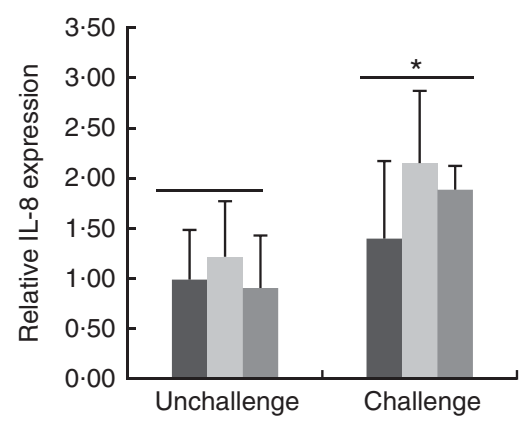

(F)

$P($ diet $)=0.032$

$P($ challenge $)=0.001$

$P($ interaction $)=0.024$

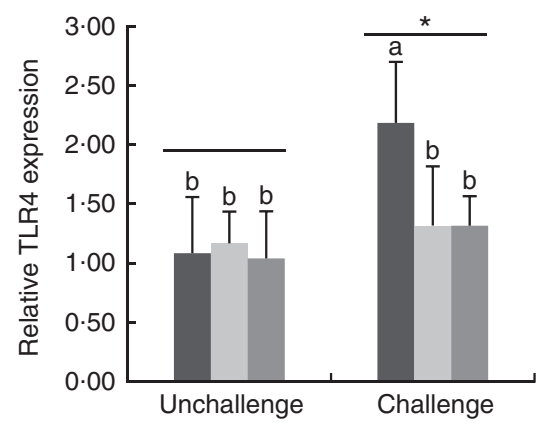

Fig. 1. Effects of dietary treatments (control, mannan-oligosaccharide (MOS) and live yeast (LY)) on the expressions of inflammation-related genes (IL-1 $\beta$ (A), TNF- $\alpha$ (B), IL-10 (C), IL-8 (D), NF-KB (E), Toll-like receptor $4(T L R 4)(F))$ in the ileum of broilers challenged with Escherichia coli. Values are means $(n 9)$ and standard deviations represented by vertical bars. ${ }^{*}$ Suggests significant main effect $(P<0.05)$ of $E$. coli challenge. ${ }^{\mathrm{a}, \mathrm{b}, \mathrm{c}}$ Treatments with unlike letters are significantly different $(P<0.05)$. $\square$, Control; $\square$, MOS; $\square$, LY.

provide the optimal effect for broilers because of immature intestinal function ${ }^{(26)}$.

Endotoxin is a part of the cell wall of gram-negative bacteria, whereas DAO is a highly active intracellular enzyme in intestinal villi ${ }^{(27)}$. They are released into circulation when the intestinal barrier is destroyed, and their levels in blood can be used as indicators for monitoring the extent of intestinal injury $^{(27,28)}$. In the present study, we observed increases in serum endotoxin and DAO levels in challenged birds, suggesting the idea of an increase in intestinal permeability and an impairment of barrier function after E. coli challenge. In support of this view, we found that $E$. coli challenge also exerted negative effects on intestinal maltase activity (brushborder enzyme) and morphological structure, a marker of intestinal mucosal integrity ${ }^{(21,29)}$, confirming a disruption in the intestinal barrier by $E$. coli. It was reported that dietary MOS or LY addition was positive for brush-border enzymes production and intestinal morphology in animals ${ }^{(12,13,30,31)}$. However, a few 
(A)

$P($ diet $)=0.592$

$P$ (challenge $)=0.964$

$P($ interaction $)=0 \cdot 165$

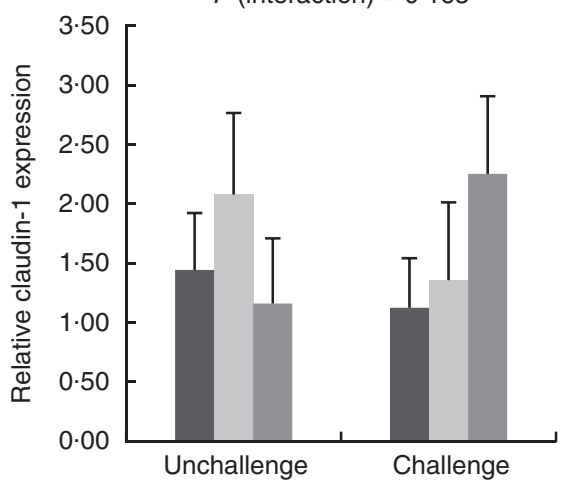

(B)

$P($ diet $)=0.384$
$P($ challenge $)=0.016$

$P$ (interaction) $=0.034$

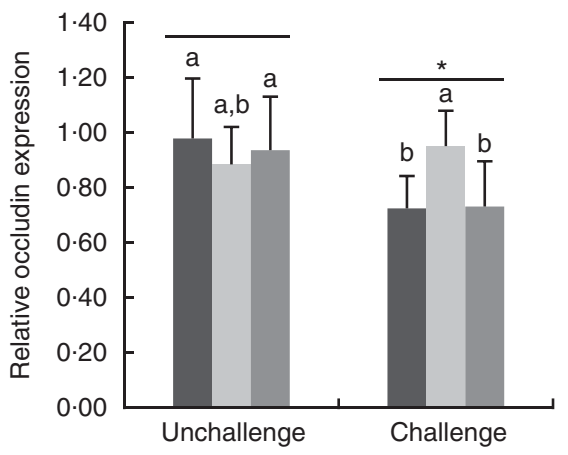

(C)

$P($ diet $)=0.312$

$P$ (challenge) $=0.085$

$P($ interaction $)=0.600$

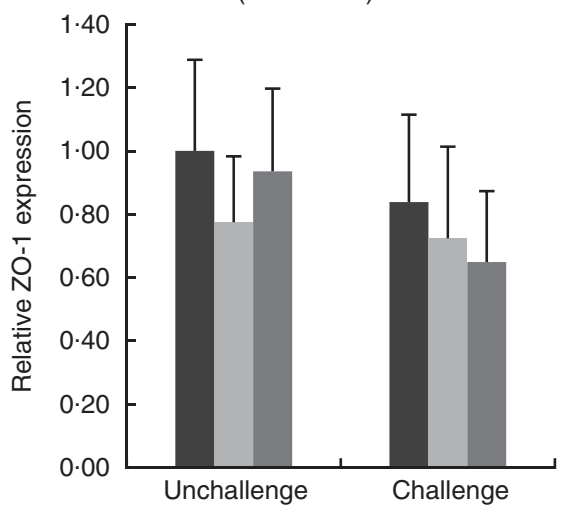

Fig. 2. Effects of dietary treatments (control, mannan-oligosaccharide (MOS) and live yeast (LY)) on the relative expressions of tight junction proteins (claudin-1 (A), occludin (B) and zonula occludens (ZO)-1 (C)) in the ileum of broilers challenged with Escherichia coli. Values are means $(n 9)$ and standard deviations represented by vertical bars. " Suggests significant main effect $(P<0.05)$ of $E$. coli challenge. ${ }^{a, b}$ Treatments with unlike letters were significantly different $(P<0.05)$. $\square$, Control; $\square$, MOS; $\square$, LY.

Table 6. Effects of dietary treatment on relative abundance (\%) of ileal bacterial taxa at the genus level (top ten) of broilers challenged with Escherichia coli (Mean values with their standard errors; $n 6$ )

\begin{tabular}{|c|c|c|c|c|c|c|c|c|c|c|c|}
\hline & E. coli & Lac & $\mathrm{CA}$ & Ent & But & Bre & Aci & Sta & Rum & Fae & Osc \\
\hline \multicolumn{12}{|l|}{ Diet } \\
\hline \multirow[t]{2}{*}{ Cont } & - & 88.75 & 1.78 & 0.134 & 0.0202 & 0.0029 & 0.0173 & 0.0019 & 0.0260 & 0.0058 & 0.0159 \\
\hline & + & $96 \cdot 11$ & $2 \cdot 18$ & 0.123 & 0.0116 & 0.0101 & 0.0217 & 0.0024 & 0.0443 & 0.0380 & 0.0168 \\
\hline \multirow[t]{2}{*}{ MOS } & - & 88.77 & 3.46 & 0.274 & 0.0106 & 0.0159 & 0.0226 & 0.0010 & 0.0270 & 0.0053 & 0.0116 \\
\hline & + & 97.63 & 0.98 & 0.105 & 0.0149 & 0.0034 & 0.0120 & 0.0034 & 0.0501 & 0.0067 & 0.0106 \\
\hline \multirow[t]{2}{*}{ LY } & - & $93 \cdot 76$ & $3 \cdot 24$ & 0.462 & 0.0140 & 0.0245 & 0.0322 & $0 \cdot 1251$ & 0.0168 & 0.0091 & 0.007 \\
\hline & + & 86.53 & $2 \cdot 20$ & 0.111 & 0.1661 & 0.0168 & 0.0265 & 0.0053 & 0.1146 & 0.1083 & 0.0809 \\
\hline SEM & & 1.301 & 0.577 & 0.0280 & 0.02212 & 0.00268 & 0.00564 & 0.01934 & 0.01194 & 0.01456 & 0.01209 \\
\hline \multicolumn{12}{|l|}{ Main effects } \\
\hline Cont & & 92.43 & 1.98 & 0.129 & 0.0159 & 0.0065 & 0.0195 & 0.0022 & 0.0351 & 0.0219 & 0.0164 \\
\hline MOS & & $93 \cdot 20$ & $2 \cdot 22$ & 0.189 & 0.0128 & 0.0096 & 0.0173 & 0.0022 & 0.0385 & 0.0060 & 0.0111 \\
\hline \multirow[t]{3}{*}{ LY } & & $90 \cdot 15$ & $2 \cdot 72$ & 0.286 & 0.0900 & 0.0207 & 0.0294 & 0.0652 & 0.0657 & 0.0587 & 0.0440 \\
\hline & - & 90.43 & 2.83 & $0.290^{\mathrm{a}}$ & 0.0149 & 0.0144 & 0.0241 & 0.0427 & 0.0233 & 0.0067 & 0.0116 \\
\hline & + & 93.43 & 1.78 & $0 \cdot 113^{\mathrm{b}}$ & 0.0642 & 0.0101 & 0.0201 & 0.0037 & 0.0696 & 0.0510 & 0.0361 \\
\hline \multicolumn{12}{|l|}{$P$} \\
\hline Diet & & 0.613 & 0.867 & 0.084 & 0.287 & 0.091 & 0.654 & 0.321 & 0.526 & 0.330 & 0.497 \\
\hline E. coli & & 0.259 & 0.375 & 0.004 & 0.275 & 0.424 & 0.725 & 0.321 & 0.062 & 0.139 & 0.318 \\
\hline Interaction & & 0.052 & 0.602 & 0.061 & 0.273 & 0.306 & 0.860 & 0.348 & 0.327 & 0.387 & 0.369 \\
\hline
\end{tabular}

Lac, Lactobacillus; CA, Candidatus arthromitus; Ent, Enterococcus; But, Butyricicoccus; Bre, Brevibacillus; Aci, Acinetobacter, Sta, Staphylococcus; Rum, Ruminococcus; Fae,

Faecalibacterium; Osc, Oscillospira; Cont, control; MOS, mannan-oligosaccharide; LY, live yeast.

${ }^{\mathrm{a}, \mathrm{b}}$ Mean values within a column with unlike superscript letters are significantly different $(P<0.05)$. 
studies have been carried out to study their effects on intestinal structure of broilers under challenged conditions. In the present study, there was an increasing trend for ileal $\mathrm{VH}$ and an enhanced VCR in response to dietary treatment with both LY and MOS, revealing an improvement in ileal villi structure of LY- and MOS-treated birds, which could be helpful for the intestinal barrier of broilers against $E$. coli challenge. In addition, this result coincided with the alleviation of the increased serum DAO and endotoxin levels in challenged birds treated with both MOS and LY.

Tight junctions (TJ) are composed of several unique proteins, which create a paracellular permeability barrier and act as a fence preventing macromolecular translocation ${ }^{(32)}$. Following E. coli challenge, we found destruction in intestinal TJ,

Table 7. Effects of dietary treatment on the a diversity metric of ileal microbiota of broilers challenged with Escherichia coli

(Mean values with their standard errors; $n 6$ )

\begin{tabular}{lccccc}
\hline & E. coli & $\begin{array}{c}\text { Shannon } \\
\text { index }\end{array}$ & $\begin{array}{c}\text { Simpson } \\
\text { index }\end{array}$ & $\begin{array}{c}\text { Chao1 } \\
\text { index }\end{array}$ & $\begin{array}{c}\text { ACE } \\
\text { index }\end{array}$ \\
\hline Diet & & & & & \\
Cont & - & $1.81^{\mathrm{b}, \mathrm{c}}$ & $0.56^{\mathrm{b}, \mathrm{c}}$ & 79.56 & 85.98 \\
& + & $1.84^{\mathrm{b}, \mathrm{c}}$ & $0.59^{\mathrm{b}, \mathrm{c}}$ & 66.31 & 71.78 \\
MOS & - & $2.11^{\mathrm{a}, \mathrm{b}}$ & $0.67^{\mathrm{a}, \mathrm{b}}$ & 85.48 & 89.79 \\
& + & $1.50^{\mathrm{c}}$ & $0.46^{\mathrm{c}}$ & 79.20 & 84.83 \\
LY & - & $1.93^{\mathrm{b}, \mathrm{c}}$ & $0.61^{\mathrm{a}, \mathrm{b}, \mathrm{c}}$ & 72.74 & 79.76 \\
& + & $2.55^{\mathrm{a}}$ & $0.77^{\mathrm{a}}$ & 108.72 & 113.53 \\
SEM & & 0.067 & 0.023 & 4.241 & 4.168 \\
Main effects & & & & & \\
Cont & & $1.83^{\mathrm{b}}$ & $0.58^{\mathrm{b}}$ & 72.94 & 78.88 \\
MOS & & $1.80^{\mathrm{b}}$ & $0.57^{\mathrm{b}}$ & 82.34 & 87.31 \\
LY & & $2.24^{\mathrm{a}}$ & $0.69^{\mathrm{a}}$ & 90.73 & 96.64 \\
& - & 1.95 & 0.61 & 79.26 & 85.17 \\
& + & 1.96 & 0.61 & 84.74 & 90.05 \\
P & & & & & \\
Diet & & 0.021 & 0.048 & 0.246 & 0.236 \\
E. coli & & 0.938 & 0.929 & 0.523 & 0.563 \\
Interaction & & 0.003 & 0.009 & 0.051 & 0.059 \\
\hline
\end{tabular}

Cont, control; MOS, mannan-oligosaccharide; LY, live yeast; ACE, abundance-based coverage estimator.

a,b,c Mean values within a column with unlike superscripts letters are significantly different $(P<0.05)$.

(a)

PCA plot

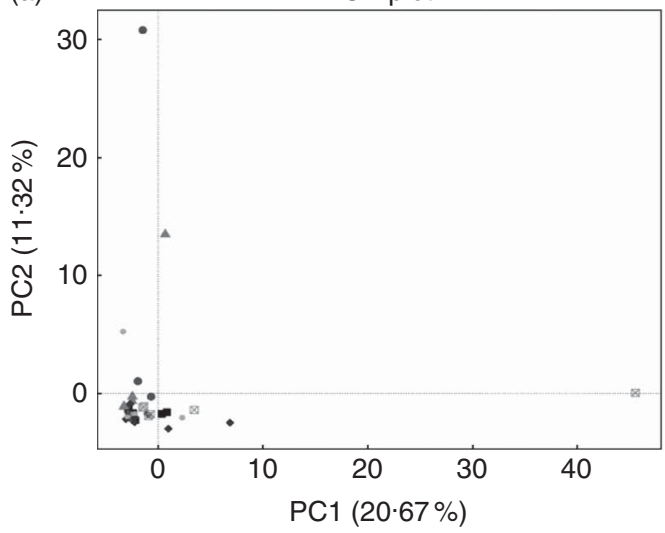

characterised by the reduced occludin and $Z O-1$ expressions in the ileum. This was similar to some previous studies ${ }^{(3,33)}$. Decreased expression of TJ proteins was correlated with an increased intestinal permeability and a disruption of the intestinal barrier, thereby allowing the transmission of macromolecules from the intestinal lumen into blood circulation ${ }^{(34)}$. This could conduce to elevated serum endotoxin and DAO levels of challenged birds. Recent studies have evidenced that treatment with some prebiotics and probiotics could up-regulate the expressions of intestinal $\mathrm{TJ}$ proteins in animals ${ }^{(35-39)}$. However, it was unknown whether MOS or LY could impact TJ profile in broilers. In the present study, MOS inclusion restored the reduced expression of ileal occludin in challenged birds. These results support the idea that dietary MOS addition could be, to a degree, beneficial for the TJ structure of broilers after $E$. coli challenge, by which it might be implicated in tightening intestinal permeability.

Lipopolysaccharides of gram-negative bacteria such as E. coli can be detected by TLR4, the stimulation of which activates downstream signalling such as $N F-k B$ leading to the sharp increase in synthesis and release of pro-inflammatory cytokines, thereby resulting in tissue damage along with high consumption of nutrients ${ }^{(40,41)}$. Similar to the previous studies ${ }^{(39,42)}$, we found increases in ileal TLR- $4, N F-\kappa B, I L-1 \beta$ and $I L-8$ expression in challenged birds, demonstrating that $E$. coli-induced intestinal inflammatory responses probably through the TLR4/NF- $K B$ signalling pathway. As inflammatory responses are involved in the recruitment of phagocytes to the infection site ${ }^{(43)}$, it could be deduced that products of phagocytes in the infection site would be increased. Indeed, we found that $E$. coli challenge elevated the activities of ileal lysozyme and MPO, which are produced by activated macrophages and neutrophils and serve as a marker for evaluating the degree of inflammation ${ }^{(44,45)}$, providing another clue for intestinal inflammation in challenged birds. It has been shown that dietary MOS addition exerted an anti-inflammatory role in pigs confronted with immunological stress, as revealed by the reduced expression of intestinal pro-inflammatory cytokines and increased expression of anti-inflammatory cytokines ${ }^{(46)}$. Similar effects were also

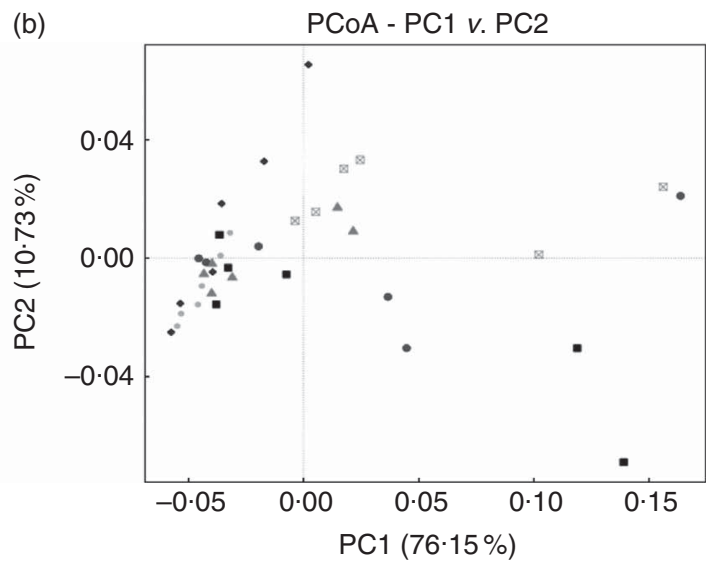

Fig. 3. Effects of dietary treatment on community similarity of ileal microbiota of broilers challenged with Escherichia coli ( $n$ 6). (a) Principal component analysis (PCA) and (b) principal coordinates analysis (PCoA) of ileal microbiota. $\mathbf{c}$, Control group and received challenge; 9 , mannan-oligosaccharide (MOS)-treated group and received challenge; $\triangle$, live yeast (LY)-treated group and received challenge; $\uparrow$, control group and free from challenge; $\bigcirc$, MOS-treated group and free from challenge; $\mathbb{Q}$, LY-treated group and free from challenge. 
observed for LY treatment, which prevented $E$. coli-induced increase in intestinal TLR4 expression in pigs ${ }^{(15)}$, and inhibited the expression of intestinal pro-inflammatory cytokines in response to pathogen invasion in mice ${ }^{(18)}$ and in vitro ${ }^{(19,20)}$. In this study, we observed that dietary treatment with both MOS and LY reduced ileal MPO activity, and simultaneously alleviated the increased expressions of ileal $I L-1 \beta, T L R 4$ and $N F-\kappa B$ in challenged birds. These results suggest that both MOS and LY addition relieved the inflammatory infiltration of the ileum to some degree and exerted active roles in reducing massive production of ileal pro-inflammatory cytokines following $E$. coli challenge probably through the inhibition of $T L R 4 / N F-\kappa B$ pathway. Attenuated local inflammation had been suggested to be associated with the alleviation of intestinal morphology impairment $^{(47)}$. Therefore, the suppression of TLR 4 pathway in the present study might partially contribute to the mitigation of ileal villus damage. $I L-1 O$ is a pivotal anti-inflammatory cytokine secreted by activated macrophages that serves to maintain immune balance by suppressing the excessive production of pro-inflammatory cytokines ${ }^{(48)}$. Accordingly, increase in ileal $I L-10$ expression of challenged birds might also be related to the alleviation of $E$. coli-induced intestinal inflammation of broilers fed MOS.

Gut microbiota conduce to maintain the physiological structure and function of the intestine ${ }^{(49)}$, which are understood to be associated with intestinal inflammation and barrier function as well as growth performance of the host ${ }^{(50-52)}$. In this study, although $E$. coli challenge decreased the relative abundance of ileal Enterococcus and tended to increase the abundance of ileal Ruminococcus, it did not affect the majority of microorganism, especially the predominant member (Lactobacillus) in the ileum. Therefore, it could be concluded that E. coli challenge altered the composition of ileal microbiota in broilers, but these changes were minor in nature. This is similar to a previous report by Videnska et al. ${ }^{(53)}$, who thought that bacteria-induced intestinal disruption of chickens was characterised more as an indirect consequence of the infection and inflammation instead of a positively selected evolutionary trait. It was indicated that intestinal microflora of animals could be modulated by the addition of $\operatorname{MOS}^{(54,55)}$ or $\mathrm{LY}^{(11,12)}$. In the present study, MOS addition had little relation to the ileal microbial community; however, LY supplementation tended to increase the relative abundance of ileal Enterococcus and Brevibacillus, which are indicated to modulate intestinal microbiota and immune responses of the host, and thus considered as potential probiotics in chickens ${ }^{(36,56-59)}$. This might conduce to the alleviated intestinal inflammation of broilers fed LY. $\alpha$ Diversity of the microbial community could be reflected by Shannon and Simpson indices as well as Chao1 and ACE indices $^{(60)}$. Although PCA and PCoA revealed no obvious difference in $\beta$ diversity of the ileal microbiota between each group, LY treatment enhanced the $\alpha$ diversity of ileal microbiota, which was characterised by the increased Shannon and Simpson indices and the tendency towards elevated Chao1 and ACE indices of the ileal microbial community in challenged birds. Ecological theory suggests that species-rich community results in enhanced stability of the intestinal micro-ecology, which could be related to the reduced susceptibility to bacterial invasion and intestinal inflammation coupled with an improvement in intestinal absorption and growth performance of the host ${ }^{(60-63)}$. Therefore, overall, it could be deduced that modulation of intestinal microbial community structure, including the increased microbial diversity and the abundance of Enterococcus and Brevibacillus, was associated with the alleviated intestinal inflammation and the reduced FCR during the grower period of broilers due to LY addition.

In conclusion, the present study suggests that dietary supplementation with both MOS and LY alleviated E. coliinduced intestinal disruption by attenuating intestinal inflammation and barrier dysfunction in broilers. It is possible that the ability of MOS and LY to alleviate intestinal inflammation is associated with the suppression of $T L R 4 / N F-\kappa B$ signalling pathway. Moreover, LY addition improved intestinal microbial community structure, and this might also contribute to the alleviation of intestinal inflammation along with the improvement of feed efficiency in broilers.

\section{Acknowledgements}

The authors thank Youli Wang, Wenyi An, Ning Tian and Li Zhu (China Agricultural University, Beijing, China) for their assistance in the process of sample collection.

This study was financially supported by Phileo Lesaffre Animal Care (Marcq-en-Baroeul, Lille, France). The funder had no role in the design and analysis of the study and in the writing of this article.

W. W. conducted the animal trial, performed the sample analyses and wrote the manuscript; Z. L. and Q. H. assisted with animal feeding and data analysis; Y. G., B. Z. and R. D. contributed to the experimental design.

None of the authors had any conflicts of interest.

\section{References}

1. He CL, Fu BD, Shen HQ, et al. (2011) Xiang-Qi-Tang increases avian pathogenic Escherichia coli-induced survival rate and regulates serum levels of tumor necrosis factor alpha, interleukin-1 and soluble endothelial protein $\mathrm{C}$ receptor in chicken. Biol Pharm Bull 34, 379-382.

2. Cao GT, Zeng XF, Chen AG, et al. (2013) Effects of a probiotic, Enterococcus faecium, on growth performance, intestinal morphology, immune response, and cecal microflora in broiler chickens challenged with Escherichia coli K88. Poult Sci $92,2949-2955$.

3. Gao Y, Han F, Huang X, et al. (2013) Changes in gut microbial populations, intestinal morphology, expression of tight junction proteins, and cytokine production between two pig breeds after challenge with Escherichia coli K88: a comparative study. J Anim Sci 91, 5614-5625.

4. Ribeiro AML, Vogt LK, Canal CW, et al. (2007) Effects of prebiotics and probiotics on the colonization and immune response of broiler chickens challenged with Salmonella enteritidis. Braz J Poult Sci 9, 193-200.

5. Yang Y, Iji PA, Kocher A, et al. (2008) Effects of mannanoligosaccharide and fructooligosaccharide on the response of broilers to pathogenic Escherichia coli challenge. Br Poult Sci 49, 550-559. 
6. Levkut M, Revajová V, Lauková A, et al. (2012) Leukocytic responses and intestinal mucin dynamics of broilers protected with Enterococcus faecium EF55 and challenged with Salmonella enteritidis. Res Vet Sci 93, 195-201.

7. Penha-Filho RAC, Díazb SJA, Fernando FS, et al. (2015) Immunomodulatory activity and control of Salmonella enteritidis colonization in the intestinal tract of chickens by Lactobacillus based probiotic. Vet Immunol Immunopathol 167, 64-69.

8. Spring P, Wenk C, Dawson KA, et al. (2000) The effects of dietary mannan oligosaccharides on cecal parameters and the concentrations of enteric bacteria in the ceca of salmonellachallenged broiler chicks. Poult Sci 79, 205-211.

9. Baurhoo B, Letellier A, Zhao X, et al. (2007) Cecal populations of Lactobacilli and Bifidobacteria and Escherichia coli populations after in vivo Escherichia coli challenge in birds fed diets with purified lignin or mannanoligosaccharides. Poult Sci 86, 2509-2516.

10. Abudabos AM \& Yehia HM (2013) Effect of dietary mannan oligosaccharide from Saccharomyces cerevisiae on live performance of broilers under Clostridium perfringens challenge. Ital J Anim Sci 12, 231-235.

11. Heugten EV, Funderburke DW \& Dorton KL (2003) Growth performance, nutrient digestibility, and fecal microflora in weanling pigs fed live yeast. J Anim Sci 81, 1004-1012.

12. Haldar S, Ghosha TK, Toshiwatia, et al. (2011) Effects of yeast (Saccharomyces cerevisiae) and yeast protein concentrate on production performance of broiler chickens exposed to heat stress and challenged with Salmonella enteritidis. Anim Feed Sci Technol 168, 61-71.

13. Xiong X, Yang HS, Li B, et al. (2015) Dietary supplementation with yeast product improves intestinal function, and serum and ileal amino acid contents in weaned piglets. Livest Sci 171, 20-27.

14. Jang YD, Kang KW, Piao LG, et al. (2013) Effects of live yeast supplementation to gestation and lactation diets on reproductive performance, immunological parameters and milk composition in sows. Livest Sci 152, 167-173.

15. Badia R, Lizardo R, Martinez P, et al. (2012) The influence of dietary locust bean gum and live yeast on some digestive immunological parameters of piglets experimentally challenged with Escherichia coli. J Anim Sci 90, 260-262.

16. Trckova M, Faldyna M, Alexa P, et al. (2014) The effects of live yeast Saccharomyces cerevisiae on postweaning diarrhea, immune response, and growth performance in weaned piglets. J Anim Sci 92, 767-774.

17. Trevisi P, Colombo M, Priori D, et al. (2015) Comparison of three patterns of feed supplementation with live yeast on postweaning diarrhea, health status, and blood metabolic profile of susceptible weaning pigs orally challenged with F4ac. J Anim Sci 93, 2225-2233.

18. Jawhara S, Habib K, Maggiotto F, et al. (2012) Modulation of intestinal inflammation by yeasts and cell wall extracts: strain dependence and unexpected anti inflammatory role of glucan fractions. PLOS ONE 7, e40648.

19. Zanello G, Berri M, Dupont J, et al. (2011) Saccharomyces cerevisiae modulates immune gene expressions and inhibits ETEC-mediated ERK1/2 and p38 signaling pathways in intestinal epithelial cells. PLOS ONE 6, e18573.

20. Zanello G, Meurens F, Berri M, et al. (2011) Saccharomyces cerevisiae decreases inflammatory responses induced by F4(+) enterotoxigenic Escherichia coli in porcine intestinal epithelial cells. Vet Immunol Immunopathol 141, 133-138.

21. Lamb-Rosteski JM, Kalischuk LD, Inglis GD, et al. (2008) Epidermal growth factor inhibits Campylobacter jejuni induced claudin- 4 disruption, loss of epithelial barrier function, and Escherichia coli translocation. Infect Immun $\mathbf{7 6}$ 3390-3398.

22. Fleige S \& Pfaffl MW (2006) RNA integrity and the effect on the real-time qRT-PCR performance. Mol Aspects Med 27, 126-139.

23. Livak KJ \& Schmittgen TD (2001) Analysis of relative gene expression data using real-time quantitative PCR and the $2^{-\Delta \Delta \mathrm{Ct}}$ method. Methods 25, 402-408.

24. Santos EG, Costa FGP, Silva JHV, et al. (2012) Protective effect of mannan oligosaccharides against early colonization by Salmonella enteritidis in chicks is improved by higher dietary threonine levels. J Appl Microbiol 114, $1158-1165$

25. Rezaeipour V, Fononi H \& Irani M (2012) Effects of dietary L-threonine and Saccharomyces cerevisiae on performance, intestinal morphology and immune response of broiler chickens. S Afr J Anim Sci 42, 266-273.

26. Uni Z (1999) Functional development of the small intestine in domestic birds: cellular and molecular aspects. Poult Avian Biol Rev 10, 167-179.

27. Luk GD, Bayless TM \& Baylin SB (1980) Diamine oxidase (histaminase)-a circulating marker for rat intestinal mucosal maturation and integrity. J Clin Invest 66, 66-70.

28. Mani V, Weber TE, Baumgard LH, et al. (2012) Endotoxin, inflammation, and intestinal function in livestock. J Anim Sci 90, 1452-1465.

29. Tan JZ, Applegate TJ, Liu SS, et al. (2014) Supplemental dietary L-arginine attenuates intestinal mucosal disruption during a coccidial vaccine challenge in broiler chickens. Br J Nutr 112, 1098-1109.

30. Cheled-Shoval SL, Amit-Romach E, Barbakov M, et al. (2011) The effect of in ovo administration of mannan oligosaccharide on small intestine development during the pre- and posthatch periods in chickens. Poult Sci 90, 2301-2310.

31. Jiang ZY, Wei SY, Wang ZB, et al. (2015) Effects of different forms of yeast Saccharomyces cerevisiae on growth performance, intestinal development, and systemic immunity in early-weaned piglets. J Anim Sci Biotechnol 6, 47.

32. Ballard ST, Hunter JH \& Taylor AE (1995) Regulation of tight junction permeability during nutrient absorption across the intestinal epithelium. Annu Rev Nutr 15, 35-55.

33. Ewaschuk JB, Murdoch GK, Johnson IR, et al. (2011) Glutamine supplementation improves intestinal barrier function in a weaned piglet model of Escherichia coli infection. Br J Nutr 106, 870-877.

34. Zhang BK \& Guo YM (2009) Supplemental zinc reduced intestinal permeability by enhancing occludin and zonula occludens protein-1 (ZO-1) expression in weaning piglets. $\mathrm{Br}$ J Nutr 102, 687-693.

35. Zhou XL, Kong XF, Lian GQ, et al. (2014) Dietary supplementation with soybean oligosaccharides increases shortchain fatty acids but decreases protein-derived catabolites in the intestinal luminal content of weaned Huanjiang minipiglets. Nutr Res 34, 780-788.

36. Alizadeh A, Akbari P, Difilippo E, et al. (2016) The piglet as a model for studying dietary components in infant diets: effects of galacto-oligosaccharides on intestinal functions. Br J Nutr 115, 605-618.

37. Dong ZL, Wang YW, Song D, et al. (2016) The effects of dietary supplementation of pre-microencapsulated Enterococcus fecalis and the extract of Camellia oleifera seed on growth performance, intestinal morphology, and intestinal mucosal immune functions in broiler chickens. Anim Feed Sci Technol 212, 42-51.

38. Rajput IR, Li LY, Xin X, et al. (2013) Effect of Saccharomyces boulardii and Bacillus subtilis B10 on intestinal ultrastructure 
modulation and mucosal immunity development mechanism in broiler chickens. Poult Sci 92, 956-965.

39. $\mathrm{Li} \mathrm{Y}$, Zhang $\mathrm{H}$, Chen $\mathrm{YP}$, et al. (2015) Bacillus amyloliquefaciens supplementation alleviates immunological stress and intestinal damage in lipopolysaccharide-challenged broilers. Anim Feed Sci Technol 208, 119-131.

40. Dobrovolskaia MA \& Vogel SN (2002) Toll receptors, CD14, and macrophage activation and deactivation by LPS. Microbes Infect 4, 903-914.

41. Dinarello CA (2000) Proinflammatory cytokines. Chest 118, 503-508.

42. MacKinnon KM, He H, Nerren JR, et al. (2009) Expression profile of toll-like receptors within the gastrointestinal tract of 2-day-old Salmonella enteriditis-infected broiler chickens. Vet Microbiol 137, 313-319.

43. Gong Y, Hart E, Shchurin A, et al. (2008) Inflammatory macrophage migration requires MMP-9 activation by plasminogen in mice. J Clin Invest 118, 3012-3024.

44. Persson K, Carlsson A, Hambleton C, et al. (1992) Immunoglobulins, lysozyme and lactoferrin in the teat and udder of the dry cow during endotoxin-induced inflammation. $J$ Vet Med 39, 165-174.

45. Lavi I, Levinson D, Peri I, et al. (2010) Orally administered glucans from the edible mushroom Pleurotus pulmonarius reduce acute inflammation in dextran sulfate sodium-induced experimental colitis. Br J Nutr 103, 393-402.

46. Che TM, Johnson RW, Kelley KW, et al. (2012) Effects of mannan oligosaccharide on cytokine secretions by porcine alveolar macrophages and serum cytokine concentrations in nursery pigs. J Anim Sci $\mathbf{9 0}$, 657-668.

47. Liu Y, Huang J, Hou Y, et al. (2008) Dietary arginine supplementation alleviates intestinal mucosal disruption induced by Escherichia coli lipopolysaccharide in weaned pigs. Br J Nutr 100, 552-560.

48. Corwin EJ (2000) Understanding cytokines part I: physiology and mechanisms of action. Biol Res Nurs 2, 30-40.

49. Sekirov I, Russell SL, Antunes LC, et al. (2010) Gut microbiota in health and disease. Physiol Rev 90, 859-904.

50. Santacruz A, Collado MC, Garcia-Valdes L, et al. (2010) Gut microbiota composition is associated with body weight, weight gain and biochemical parameters in pregnant women. Br J Nutr 104, 83-92.

51. Hakansson A \& Molin G (2011) Gut microbiota and inflammation. Nutrients 3, 637-682.
52. Singh KM, Shah T, Deshpande S, et al. (2012) High through put $16 \mathrm{~S}$ rRNA gene-based pyrosequencing analysis of the fecal microbiota of high FCR and low FCR broiler growers. Mol Biol Rep 39, 595-602.

53. Videnska P, Sisak F, Havlickova H, et al. (2013) Influence of Salmonella enterica serovar enteritidis infection on the composition of chicken cecal microbiota. BMC Vet Res $9,140$.

54. Kim GB, Seo YM, Kim CH, et al. (2011) Effect of dietary prebiotic supplementation on the performance, intestinal microflora, and immune response of broilers. Poult Sci $\mathbf{9 0}$, $75-82$.

55. Corrigan A, de-Leeuw M, Penaud-Frézet S, et al. (2015) Phylogenetic and functional alterations in bacterial community compositions in broiler ceca as a result of mannan oligosaccharide supplementation. Appl Environ Microb 81, 3460-3470.

56. de Oliveira JE, van der Hoeven-Hangoor E, van de Linde IB, et al. (2014) In ovo inoculation of chicken embryos with probiotic bacteria and its effect on posthatch Salmonella susceptibility. Poult Sci 93, 818-829.

57. Ruiu L, Satta A \& Floris I (2014) Administration of Brevibacillus laterosporus spores as a poultry feed additive to inhibit house fly development in feces: a new eco-sustainable concept. Poult Sci 93, 519-526.

58. Sanders ME, Morelli L \& Tompkins TA (2003) Sporeformers as human probiotics: Bacillus, Sporolactobacillus, and Brevibacillus. Compr Rev Food Sci F 2, 101-110.

59. Samli HE, Senkoylu N, Koc F, et al. (2007) Effects of Enterococcus faecium and dried whey on broiler performance, gut histomorphology and intestinal microbiota. Arch Anim Nutr 61, 42-49.

60. Li Y, Xu Q, Huang Z, et al. (2015) Effect of Bacillus subtilis CGMCC 1.1086 on the growth performance and intestinal microbiota of broilers. J Appl Microbiol 120, 195-204.

61. Ott SJ, Musfeldt M, Wenderoth DF, et al. (2004) Reduction in diversity of the colonic mucosa associated bacterial microflora in patients with active inflammatory bowel disease. Gut $\mathbf{5 3}$, 685-693.

62. Nitzan O, Elias M, Peretz A, et al. (2016) Role of antibiotics for treatment of inflammatory bowel disease. World J Gastroenterol 22, 50-61.

63. Semova I, Carten JD, Stombaugh J, et al. (2011) Microbiota regulate intestinal absorption and metabolism of fatty acids in the Zebrafish. Cell Host Microbe 12, 277-288. 